\title{
EXPRESSÃO DE E-CADERINA E CLAUDINA-3 NO EPITÉLIO CÓLICO APÓS TERAPIA COM INFLIXIMABE: MODELO EXPERIMENTAL DE COLITE DE EXCLUSÃO
}

\author{
EXPRESSION OF E-CADHERIN AND CLAUDIN-3 IN THE COLONIC EPITHELIUM \\ AFTER THE INFLIXIMAB THERAPY: EXPERIMENTAL MODEL OF DISUSE COLITIS
}

\begin{abstract}
Antonio José Tiburcio ALVES JR ${ }^{1 \oplus}$, Eduardo Felipe Kim GOTO ${ }^{2}{ }^{\circ}$, José Aires PEREIRA ${ }^{2 \odot}$,
Fernanda Aparecida DOMINGUES ${ }^{2}$, Mariane Grandi de ÁVILA ${ }^{2 \odot}$, Claudio Saddy Rodrigues CoY $^{1 \oplus}$, Carlos Augusto Real MARTINEZ ${ }^{1,2}$
\end{abstract}

RESUMO - RACIONAL: A etiopatogenia da colite por desuso (DC) ainda não foi totalmente elucidada. As principais teorias consideram que a doença pode estar relacionada ao aumento de bactérias anaeróbias, falta de suprimento de ácidos graxos de cadeia curta (AGCC) e distúrbios imunológicos que se desenvolvem em segmentos colorretais desprovidos de trânsito fecal. OBJETIVO: Verificar se a aplicação de infliximabe modifica o conteúdo tecidual das proteínas E-caderina e claudina-3 no epitélio cólico de ratos sem trânsito intestinal. MÉTODOS: Vinte dois ratos foram submetidos a derivação do trânsito intestinal pelo procedimento de Hartmann. Eles permaneceram com o ostoma por 12 semanas para permitir o desenvolvimento da colite de exclusão. Em seguida, foram divididos em três grupos experimentais: seis animais receberam $2,0 \mathrm{ml}$ de solução salina/semana, oito infliximabe na dose de $5 \mathrm{mg} / \mathrm{Kg} / \mathrm{semana}$ e, os demais, infliximabe na dose de $10 \mathrm{mg} / \mathrm{Kg} / \mathrm{semana}$ por 5 semanas consecutivas. Em seguida, os animais foram eutanasiados e os segmentos cólicos com e sem trânsito intestinal foram removidos. A colite por desuso foi diagnosticada pelas alterações histológicas definidas por uma escala previamente validada. Expressão tecidual de E-caderina e claudina-3 foi avaliada por imuno-histoquímica, e o conteúdo tecidual de ambas as proteínas foi quantificado por análise de imagem assistida por computador. RESULTADOS: Segmentos cólicos exclusos de trânsito fecal apresentaram maior grau de inflamação do que os expostos ao trânsito fecal. Inflamação foi menor nos animais tratados com infliximabe, independente da dose utilizada. Níveis de E-caderina e claudina-3 estavam reduzidos no cólon excluso. O tratamento com infliximabe aumentou os níveis das proteínas em segmentos do cólon sem trânsito intestinal, principalmente nos animais que receberam a dose de $10 \mathrm{mg} / \mathrm{kg} / \mathrm{semana}$. CONCLUSÃO: Infliximabe reduz inflamação nos segmentos do cólon excluso e aumenta o conteúdo tecidual de E-caderina e claudina-3, especialmente na concentração de $10 \mathrm{mg} / \mathrm{kg} / \mathrm{semana}$

DESCRITORES: Colite. Cólon. Ácidos Graxos Voláteis. Infliximabe. Caderinas. Claudina-3.

ABSTRACT - BACKGROUND: The etiopathogenesis of disuse colitis (DC) has not yet been fully elucidated. The main theories consider that the disease may be related to an increase in anaerobic bacteria, the lack of short-chain fatty acid (SCFA) supply, and immunological disorders that develop in the colorectal segments devoid of fecal transit. AIM: The aim of this study was to verify whether the application of infliximab modifies the tissue content of E-cadherin and claudin-3 proteins in colonic epithelium of rats devoid of intestinal transit. METHODS: A total of 22 rats underwent intestinal transit bypass using Hartmann's procedure. They remained with the shunt for 12 weeks to allow the development of DC. Later, they were divided into three experimental groups: six animals received $2.0 \mathrm{~mL}$ saline solution/week, eight received infliximab at a dose of $5 \mathrm{mg} / \mathrm{kg} / \mathrm{week}$, and eight received infliximab at a dose of $10 \mathrm{mg} / \mathrm{kg} /$ week for 5 consecutive weeks. At the end of this period the animals were euthanized, and the colonic segments with and without intestinal transit were removed. DC was diagnosed based on the histological changes defined by a previously validated scale. The tissue expression of E-cadherin and claudin-3 was assessed by immunohistochemistry and the tissue content of both proteins was quantified by computer-aided image analysis. RESULTS: The colonic segments excluded from fecal transit showed a higher degree of inflammation than those exposed to fecal transit. The degree of inflammation was lower in animals treated with infliximab, regardless of the dose used. The levels of E-cadherin and claudin-3 were reduced in the excluded colon. Treating animals with infliximab increased the levels of both proteins in the colonic segments without intestinal transit, especially in animals receiving a dose of $10 \mathrm{mg} / \mathrm{kg} / \mathrm{week}$ CONCLUSION: Infliximab therapy reduces inflammation in the colonic segments excluded from intestinal transit and increases the tissue content of E-cadherin and claudin-3 proteins, especially when used at a concentration of $10 \mathrm{mg} / \mathrm{kg} /$ week

HEADINGS: Colitis. Fatty acids. Volatile. Infliximab. Cadherins. Claudin-3.

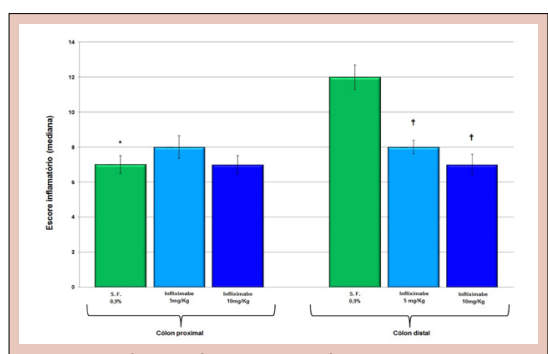

Escore inflamatório nos cólons com e sem trânsito intestinal dos animais tratados com SF $0,9 \%$, infliximabe $5 \mathrm{mg} / \mathrm{Kg} / / \mathrm{sem}$ e infliximabe $10 \mathrm{mg} / \mathrm{Kg} / \mathrm{sem}$. ${ }^{*}=p<0,05$ (SF 0,9\% sem trânsito $>\mathrm{SF} 0,9^{*}$ com trânsito). $+=p<0,05$ (Infliximabe $5 \mathrm{mg} / \mathrm{Kg} / \mathrm{sem}$ e Infliximabe $10 \mathrm{mg} / \mathrm{kg} / \mathrm{sem}$ sem trânsito < SF 0,9\% sem trânsito intestinal). Teste de Mann-Whitney.

\section{Mensagem central}

Valores de E-caderina e claudina-3 estavam reduzidos no cólon excluso. Os segmentos derivados de trânsito intestinal apresentaram maiores níveis de inflamação do que os segmentos expostos ao trânsito cólico.

\section{Perspectivas}

Infliximabe reduz o processo inflamatório da mucosa cólica exclusa de trânsito intestinal e aumenta o conteúdo tecidual de E-caderina e claudina-3, especialmente nos animais tratados com a maior dose.

Trabalho realizado no ${ }^{1}$ Departamento de Cirurgia, Faculdade de Ciências Médicas, Unicamp, Campinas - São Paulo - Brasili ${ }^{2}$ Departamento de Cirurgia, Universidade São Francisco, Bragança Paulista - São Paulo - Brasil.

Como citar esse artigo: Alves Jr AJT, Goto EFK, Pereira JA, Domingues FA, Ávila MG, Coy CSR, Martinez CAR. Expressão de e-caderina e claudina-3 no epitélio cólico após terapia com infliximabe: modelo experimental de colite de desuso. ABCD Arq Bras Cir Dig. 2021;34(4):e1639. https://doi.org/10.1590/0102-672020210002e1639

Correspondência:

Antonio José Tiburcio Alves Junior.

E-mail: antonio_xxxv@yahoo.com.br
Fonte de financiamento: Conselho Nacional de Desenvolvimento Científico e Tecnológico (CNPq) - Ministério da Ciência e tecnologia do Brasil. Número do processo: 303837/2018-7. O financiamento foi utilizado para aquisição do anticorpo primário.

Conflito de interesse: Não

Recebido: 17/08/2021

Aceito: 30/10/2021 
INTRODUÇÃO

$\mathrm{D}$ efine-se por colite de desuso (CD) o processo inflamatório que surge na mucosa de segmentos colorretais desprovidos de trânsito intestinal. Foi inicialmente descrita em 1974 por Morson e Dawson, como um processo inflamatório inespecífico que se desenvolvia em segmentos cólicos desprovidos de trânsito fecal ${ }^{21}$. Posteriormente, Glotzer et al., em 1981 mostraram o desenvolvimento de processo inflamatório crônico no epitélio intestinal de 10 pacientes, sem antecedentes de doença inflamatória intestinal (DII), que foram submetidos a colostomia ou ileostomia derivativas por diferentes condições clínicas ${ }^{10}$. Os autores constataram que em cinco doentes onde foi possível restituir o trânsito intestinal houve regressão do processo inflamatório mucoso. A partir de então, esta nova forma de colite começou a ser diagnosticada com maior frequência, porém até a presente data sua incidência é difícil de ser estabelecida ${ }^{21}$. Estudo prospectivo mostrou que a maioria dos doentes submetidos a derivação fecal e que permanecem com um segmento do cólon ou reto sem fluxo fecal a CD é diagnosticada endoscopicamente após 3-36 meses da confecção do estoma ${ }^{13,15}$.

Aetiopatogênese da $C D$ ainda não está totalmente elucidada. As principais teorias consideram que a doença possa estar relacionada a um aumento de bactérias anaeróbicas, a falta do suprimento deácidos graxos de cadeia curta (AGCC) e distúrbios imunológicos que se desenvolvem nos segmentos colorretais desprovidos de trânsito fecal. Contudo, a privação de AGCC no cólon excluso interferindo no metabolismo dos colonócitos para obtenção de energia, parece ser o mecanismo etiopatogênico com maior consenso entre os autores ${ }^{11,15,22}$. Estudos experimentais mostraram que os mecanismos moleculares provenientes da deficiência dos AGCC que promovem o desenvolvimento da CD podem estar relacionados ao aumento da produção de radicais livres de oxigênio (RLO), consequente às modificações nos mecanismos de beta-oxidação dos AGCC para obtenção de energia ${ }^{11,19,22}$. A energia decorrente do metabolismo dos AGCC, cujo principal representante é o butirato, estimula o crescimento das células colônicas, aumenta o fluxo sanguíneo mucoso, incrementa a síntese de diferentes proteínas, influência na mobilidade celular e favorece a cicatrização de lesões na parede intestinal15. Os RLO, por sua vez, são radicais tóxicos para células ocasionando peroxidação das membranas celulares, destruição de organelas celulares e, dano ao DNA celular ${ }^{19,25}$. Todavia, os tecidos possuem mecanismos de defesa contra os efeitos deletérios dos RLO, sendo estes naturais, enzimáticos e não enzimáticos, responsáveis pelo equilíbrio entre produção e eliminação dos agentes oxidativos ${ }^{25}$. $O$ tecido do intestino grosso apresenta deficiência desses sistemas antioxidantes, fazendo com que o desequilíbrio pró-oxidante determine o surgimento de uma situação de estresse oxidativo ocasionando a ruptura dos sistemas de defesa que formam a barreira epitelial desencadeando a inflamação crônica que caracteriza a $C D^{25}$.

$\mathrm{O}$ estresse oxidativo desencadeado pelas modificações dos mecanismos de respiração celular, compromete todos os mecanismos de defesa que formam a barreira epitelial cólica representados pela camada de muco que recobre o epitélio colorretal, as membranas citoplasmáticas das proteínas que formam os mecanismos de junções intercelulares e as proteínas constituintes da matriz extracelular ${ }^{19}$.

Os resultados encontrados em três estudos experimentais mostraram que no epitélio cólico por 12 e 18 semanas, houve redução significativa do conteúdo dos vários subtipos de mucinas quando comparados aos segmentos com trânsito provido de trânsito fecal $\left.\right|^{2,2,23}$. Também se identificou que a deficiência de AGCC reduz a expressão tecidual de MUC-1, MUC-3 e MUC- $4^{7}$. O aumento da produção de RLO na mucosa no cólon excluso, também reduz as proteínas que compõe as junções intercelulares, vulnerabilizando, ainda mais a barreira epitelial cólica. O conteúdo tecidual destas proteínas reflete, indiretamente, a integridade das junções intercelulares ${ }^{9,12}$. Demonstrou-se experimentalmente em modelo de CD que existe redução substancial no conteúdo tecidual das proteínas, E-caderina, $\beta$-catenina, claudina- 3 e ocludina, em segmentos cólicos desprovidos de trânsito intestinal, relacionados ao tempo de exclusão ${ }^{12,17,18}$. De modo distinto, a aplicação de enemas contendo AGCC ou substâncias com atividades antioxidante ou anti-inflamatória, como a n-acetilcisteína e a mesalazina aumentam o conteúdo tecidual tanto das mucinas quanto das proteínas constituintes das junções intercelulares, restabelecendo a integridade epitelial $2,4,7,16,18,24$.

Recentemente, estudo experimental demonstrou os efeitos benéficos da terapia biológica com infliximabe no tratamento da $\mathrm{CD}^{3}$. O infliximabe reduziu o processo inflamatório mucoso e a infiltração de células inflamatórias na mucosa e submucosa do cólon excluso ${ }^{3}$. Quando se considera que a terapia biológica, em especial com infliximabe é considerada a opção terapêutica mais eficiente para o tratamento das DII ${ }^{27}$. Sendo assim, é possível que seu uso na CD possa, da mesma forma, reduzir a inflamação e preservar os sistemas de defesa epitelial. Todavia, essa possibilidade ainda não foi avaliada clínica ou experimentalmente em modelos de CD.

Assim, o objetivo deste estudo é avaliar, a ação da terapia biológica com infliximabe no conteúdo tecidual de E-caderina e claudina-3, em modelo experimental de CD.

\section{MÉTODOS}

Utilizou-se 22 ratos Wistar (Rattus norvegicus albinus), machos, provenientes da ANILAB (Animais de Laboratório Criação e Comércio, Laboratórios Veterinários) com média de idade de quatro meses e peso variando entre 270 e $300 \mathrm{~g}$. A realização deste estudo obedeceu à Lei Federal 6.638 e às orientações do Colégio Brasileiro de Experimentação Animal (COBEA). O estudo foi aprovado pelo Comitê de Ética no Uso de Animal em Pesquisa da Universidade São Francisco, através do número 0102262014.

\section{Técnica cirúrgica}

Assim que os animais chegaram ao Biotério Central da Universidade São Francisco em Bragança Paulista, foram confinados, por sete dias, em gaiolas individuais para aclimatação. Nesse período, recebendo ração específica para roedores e água a vontade. Na véspera do dia programado para a realização do desvio do trânsito fecal foram mantidos em jejum, exceto água, por 12 horas. No dia da intervenção foram anestesiados utilizando-se o cloridrato de cetamina $(5 \mathrm{mg} / \mathrm{kg}$ ), associado ao cloridrato de xilazina $(60 \mathrm{mg} / \mathrm{kg}$ ) aplicados por via intraperitoneal. Para a abertura da parede abdominal realizouse incisão mediana, infra umbilical, com quatro centímetros de extensão. Após a abertura da cavidade abdominal identificou-se a placa de Peyer, reparo anatômico utilizado para uniformizar a secção do cólon realizada, em todos os animais $8 \mathrm{~cm}$ acima da extremidade cranial da estrutura. Após secção do cólon o segmento cranial foi exteriorizado no hipocôndrio esquerdo como colostomia terminal, enquanto o distal foi cateterizado com sonda de polivinil e irrigado com $40 \mathrm{ml}$ de soro fisiológico $0,9 \%$ com objetivo de remover resíduos fecais. Concluída a limpeza o colón distal foi excluso de trânsito pelo fechamento com sutura contínua.

\section{Pós-operatório}

Após a recuperação anestésica liberou-se a ingestão de água e, após seis horas, ração padronizada para roedores (Nuvilab 
CR1O ${ }^{\circledR}$ Nuvital Nutrientes AS, Brasil). Os ratos permaneceram em gaiolas individuais por 12 semanas depois do procedimento cirúrgico, para que se produzisse a $\mathrm{CD}$ no cólon desprovido de trânsito em todos os ratos, tempo mais que suficiente para desenvolver a doença e, portanto, possibilitar início da intervenção. Esse período de exclusão foi estabelecido, seguindo a proposta de estudos anteriormente publicados ${ }^{19,23,29}$.

\section{Grupos experimentais}

Os animais foram divididos, aleatoriamente, em três grupos experimentais segundo a solução a ser administrada: Grupo A - Solução fisiológica 0,9\% $(n=6)$;

Grupo B: Infliximabe na dose de $5 \mathrm{mg} / \mathrm{kg} / \mathrm{semana}(\mathrm{n}=8)$; Grupo C: Infliximabe na dose de $10 \mathrm{mg} / \mathrm{kg} / \mathrm{semana}(\mathrm{n}=8)$.

Administrou-se as soluções uma vez por semana, durante cinco semanas consecutivas, sempre por via subcutânea, na região posterior da prega cutânea cervical. Concluída as 5 semanas de intervenção, todos os animais foram eutanasiados em um mesmo dia.

\section{Coleta das amostras para estudo histológico}

Para remoção dos espécimes de cólon a seremencaminhados para estudo histológico, todos os roedores foram novamente anestesiados com a mesma técnica anteriormente descrita. Aberta a cavidade abdominal, os segmentos cólicos com e sem trânsito foram removidos e abertos, longitudinalmente, pela borda anti-mesocólica e lavados com PBS. De cada segmento cólico removido foram ressecados três segmentos com $1 \mathrm{~cm}$ de extensão. Esses três segmentos (dos cólons providos e desprovidos de trânsito fecal) foram encaminhados para os estudos histológicos e imuno-histoquímico. Terminada a remoção dos segmentos de cólon, os animais foram eutanasiados por injeção intra-cardíaca de dose letal de tiopental sódico $(120 \mathrm{mg} / \mathrm{kg}$ ) A morte dos animais foi definida quando não houvesse mais reflexos córneo-palpebrais e de batimentos cardíacos.

\section{Análise histológica}

Para o estudo histológico os espécimes de cólon removidos permaneceram fixados em formalaldeído tamponado à $10 \%$, por 72 horas. A seguir foram desparafinizados em xilol e desidratados em concentrações crescentes de álcool. Concluída esta fase o material foi incluído em blocos de parafina e submetido a cortes longitudinais, com $4 \mu$ de espessura, para confecção das lâminas histológicas. Concluída a montagem as lâminas foram coradas pelas técnicas da hematoxilina-eosina (para análise das alterações histológicas dos espécimes), e imuno-histoquímica para estudo da expressão tecidual das proteínas E-caderina e claudina-3.

A avaliação de todas as lâminas foi feita em microscópio óptico comum com magnificação final de 200x. A leitura foi sempre realizada por patologista experiente em enfermidades do trato digestivo que não conhecia a origem do material encaminhado.

A atividade da CD e o grau de inflamação tecidual foi avaliada segundo escala anteriormente proposta ligeiramente modificada em três campos cirúrgicos distintos ${ }^{6}$. Foram considerados os seguintes parâmetros: infiltração de células inflamatórias (linfócitos, neutrófilos e eosinófilos), presença de erosões epiteliais, atrofia das glândulas cólicas e congestão da camada submucosa. Cada variável foi estratificada de acordo com o modelo ausência (0), leve (1), moderada (2) e grave (3). Para cada segmento cólico em cada animal esses valores poderiam variar de 0 a 12. Os valores considerados para cada animal foi a mediana encontrada após a leitura de três campos distintos.

\section{Técnica imuno-histoquímica}

Para o estudo imuno-histoquímico utilizou-se técnica anteriormente padronizada. Para identificação da proteína
E-caderina nos tecidos utlizou-se anticorpo primário anti-Ecaderina (Dako Cytomation ${ }^{\circledR}$, Copenhagen, Dinamarca), diluído em albumina bovina (Sigma ${ }^{\circledR}$, Saint Louis, EUA) na concentração de 1:100. Para identificação da proteína claudina-3 no tecido cólico utilizou-se anticorpo primário anti-claudina-3 (Anti-Claudin 3, C-Terminal antibody produced in rabbit - Sigma-Aldrich, Merck KGaA, Darmstadt, Germany), diluído em albumina bovina (Sigma $^{\circledR}$, Saint Louis, EUA) na concentração de 1:100. Todas as lâminas foram cobertas com cerca de $100 \mu \mathrm{L}$ dessa solução, mantidas por 30 minutos à temperatura ambiente e levadas para câmara úmida em refrigeração a 4 graus $C$ por 24 horas. Após esse período de incubação, foram lavadas com PBS por cinco minutos, gotejadas com o anticorpo secundário específico (Dako Cytomation ${ }^{\circledR}$, Copenhagen, Dinamarca), na diluição de 1:160 em PBS, e reservadas em câmara úmida durante uma hora à temperatura ambiente. A seguir, nova lavagem com PBS por cinco minutos e aplicação do complexo estreptavidinabiotina-peroxidase (Dako Cytomation ${ }^{\circledast}$, Copenhagen, Dinamarca) preparado no momento de sua utilização, na diluição de 1:100 em PBS, por 45 minutos. As lâminas foram reveladas usandose cromógeno (tetrahidrocloridrato de diaminobenzidina $D A B$ $10 \mathrm{mg}$ em $10 \mathrm{ml}$ de PBS $+3 \mathrm{~mL}$ de água oxigenada), preparado cinco minutos antes de terminar o tempo de exposição ao complexo $A B C$, permanecendo sobre elas por três minutos. Completado este tempo, as lâminas foram lavadas em água corrente destilada por cinco minutos, contra-coradas com hematoxilina de Harris por 30 segundos, novamente lavadas em água corrente destilada, para em seguida serem desidratadas, por submersão em etanol 50\%, 80\%, 95\% e absoluto e em xilol. Finalmente as lâminas foram montadas, rotuladas e mantidas em posição horizontal por 24 horas. O controle positivo foi realizado conforme orientação do fabricante em tecidos de cólon humano que sabidamente expressem a imunocoloração para E-caderina/claudina-3, enquanto o controle negativo foi realizado com lâminas confeccionadas, com a mesma técnica, sem adição do anticorpo primário.

Para análise microscópica foi utilizado microscópio óptico comum, com magnificação final de 200 vezes. Foi considerado como reação positiva à coloração que ocorreu de modo difuso, com pontos de intensidade variáveis e distribuição homogênea. A interpretação da coloração imuno-histoquímica foi feita por patologista experiente com a técnica sem acesso aos demais dados da pesquisa. A expressão tecidual do anticorpo primário estudado foi classificada segundo a presença ou ausência de imunoreação. Considerou-se imunocoloração positiva quando mais de $10 \%$ do tecido estudado apresentou imunoreação positiva. Adotou-se como valor individual final à média entre a leitura de três campos histológicos distintos.

\section{Análise de imagem assistida por computador}

A quantificação do conteúdo tecidual das proteínas E-caderina e claudina-3 foi mensurada por programa de análise de imagens assistida por computador. Para medida do conteúdo tecidual das proteínas supracitadas utilizou-se microscópio ótico comum, com magnificação final de 200 vezes. A medida foi sempre realizada em três campos histológicos em que existissem pelo menos três criptas íntegras em toda sua extensão. A imagem selecionada foi capturada por câmera de vídeo previamente acoplada a microscópico ótico (Eclipse DS50 ${ }^{\mathrm{TM}}$ - Nikon Inc., Japan). A imagem capturada foi processada e analisada pelo programa NIS-Elements ${ }^{\mathrm{TM}}$ (Nikon Inc., Japan). O programa, através de histogramas de cor determinava a intensidade de cor de cada área previamente selecionada, transformando a cor escolhida em expressão numérica porcentual para cada campo de visão selecionado. O valor final adotado para cada campo mensurado nos segmentos provido e desprovido de trânsito intestinal foi representado pela média dos valores encontrados na avaliação de três campos diferentes. Para a quantificação 
das proteínas E-caderina e claudina-3 o sistema RGB (red, green, blue) selecionou a coloração marrom, cuja intensidade foi captada por número de pixels e posteriormente convertida em valor numérico em porcentagem por campo (\% / campo).

\section{Análise estatística}

O tamanho da amostra foi definido estatisticamente através de fórmula para cálculo amostral. Para a determinação dos valores encontrados após as medidas de cada variável em cada segmento cólico (com e sem trânsito fecal) e em cada grupo experimental (SF 0,9\%, infliximabe $5 \mathrm{mg} / \mathrm{kg} / \mathrm{sem}$ e infliximabe $10 \mathrm{mg} / \mathrm{kg} / \mathrm{sem}$ ) utilizou-se estatística descritiva e os resultados foram expressos pela mediana. Para avaliação do padrão de distribuição amostral utilizou-se o teste de Kolmogorov-Smirnov. Para a análise das variáveis utilizou-se teste de mediana (escore inflamatório) e o teste não-paramétrico de Mann-Whitney adotando-se nível de significância de $5 \%(p<0,05)$. Os resultados significantes obtidos quando se comparou de forma pareada os valores obtidos nos cólons com e sem trânsito fecal foram marcados com um asterisco $\left(^{*}\right)$ quando o valor de $p$ era menor que $5 \%(p<0,05)$ e com dois asteriscos $\left(^{* *}\right)$ quando menor que $1 \%(p<0,01)$. Os resultados significantes obtidos quando se comparou de forma pareada os valores obtidos nos animais submetidos a intervenção com SF 0,9\%, infliximabe $5 \mathrm{mg} / \mathrm{kg} / \mathrm{sem}$ e infliximabe $10 \mathrm{mg} / \mathrm{kg} / \mathrm{sem}$, dentro de um mesmo segmento cólico (com ou sem trânsito intestinal) foram marcados com uma cruz $\left(^{\dagger}\right)$ quando o valor de p era menor que $5 \%(p<0,05)$ e com duas cruzes $(++)$ quando menor do que $1 \%(p<0,01)$.

\section{RESULTADOS}

Nas Figuras 1A, 1B e $1 \mathrm{C}$ observa-se a mucosa cólica provida de trânsito intestinal após SF 0,9\%, infliximabe $5 \mathrm{mg} / \mathrm{Kg} / \mathrm{sem}$ e infliximabe $10 \mathrm{mg} / \mathrm{Kg} / \mathrm{sem}$, respectivamente, após 5 semanas de intervenção. Verifica-se que a mucosa dos animais com trânsito fecal preservado que receberam SF 0,9\% ou infliximabe (nas duas posologias), mostrava-se íntegra, com padrão de distribuição normal das glândulas cólicas, preservação da população de células caliciformes, camadas histológicas estruturadas e ausência de sinais de inflamação, fibrose e infiltrado inflamatório.

Nas Figuras 2A, 2B e 2C observa-se a mucosa cólica desprovida de trânsito intestinal nos animais tratados com SF $0,9 \%$, infliximabe $5 \mathrm{mg} / \mathrm{Kg} / \mathrm{sem}$ e infliximabe $10 \mathrm{mg} / \mathrm{Kg} / \mathrm{sem}$, respectivamente por 5 semanas. Na Figura 2A observa-se que houve redução da altura e arquitetura das glândulas que mostravam desarranjo no seu padrão de distribuição e alinhamento, redução da espessura da camada mucosa e perda de continuidade entre os colonócitos. De modo distinto, nas Figuras $2 \mathrm{~B}$ e $2 \mathrm{C}$ que representam o cólon excluso de trânsito fecal dos animais submetidos ao infliximabe, independente da

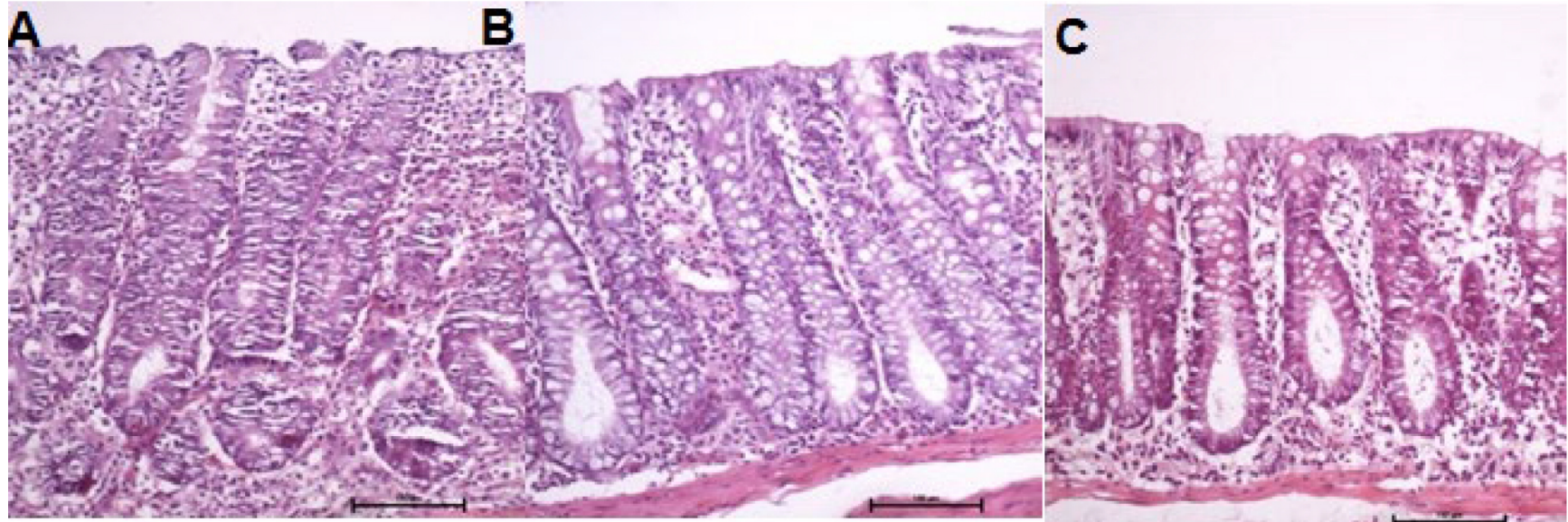

Figura 1 - A: Mucosa cólica provida de trânsito intestinal dos animais com SF 0,9\%. B: Mucosa cólica com trânsito intestinal dos animais com infliximabe na dose de $5 \mathrm{mg} / \mathrm{Kg} / \mathrm{sem}$. C: Mucosa cólica com trânsito intestinal nos animais com infliximabe na dose de $10 \mathrm{mg} / \mathrm{Kg} / \mathrm{sem}$ (HE: 200x).

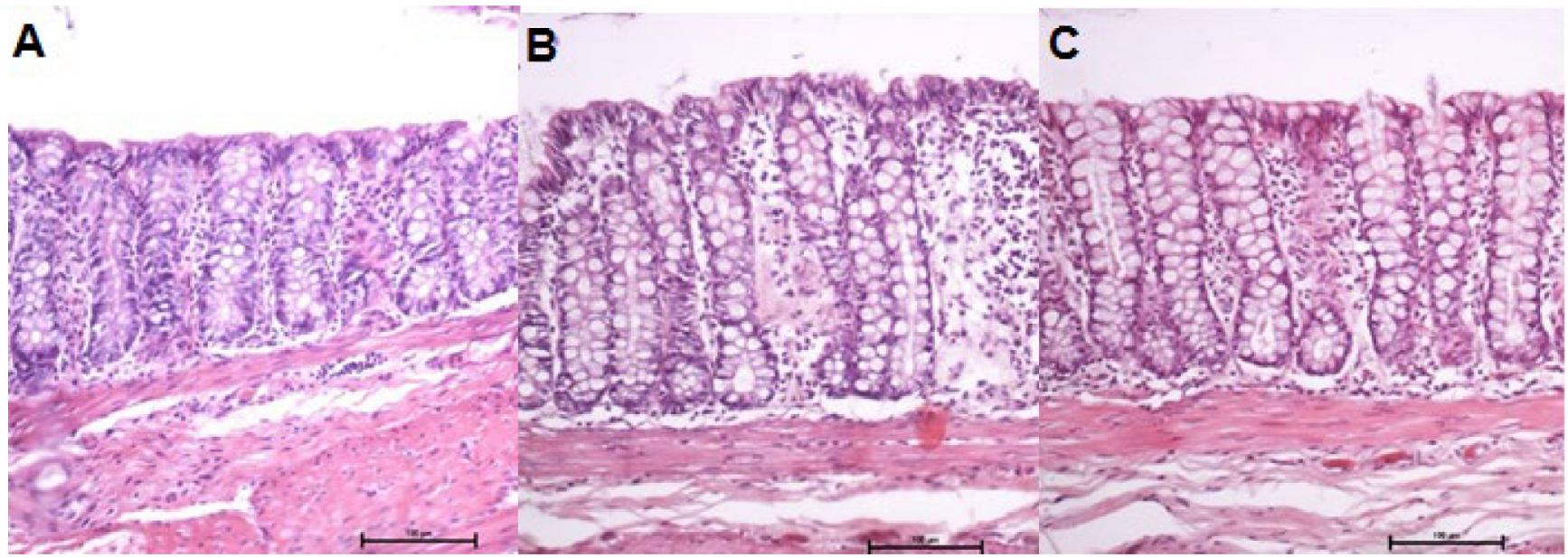

Figura 2 - A: Mucosa cólica sem trânsito intestinal dos animais com SF 0,9\%. B: Mucosa desprovida de trânsito intestinal dos animais com infliximabe na dose de $5 \mathrm{mg} / \mathrm{Kg} / \mathrm{sem}$. C: Mucosa cólica sem trânsito fecal nos animais com infliximabe na dose de $10 \mathrm{mg} / \mathrm{Kg} / \mathrm{sem}$ (HE: 200x) 
dose usada, a mucosa cólica estava alinhada, com espessura preservada, as glândulas cólicas apresentavam padrão de distribuição normal com maior população de células caliciformes.

A Figura 3 ilustra o escore inflamatório comparando os cólons proximal e distal nos animais que receberam SF 0,9\%, infliximabe na dose de $5 \mathrm{mg} / \mathrm{Kg} / \mathrm{sem}$ e infliximabe $10 \mathrm{mg} / \mathrm{Kg} / \mathrm{sem}$

$\mathrm{Na}$ Figura 4A, 4B e 4C observa-se a expressão tecidual da proteína E-caderina, na mucosa cólica com trânsito fecal dos animais tratados por cinco semanas consecutivas com SF $0,9 \%$, infliximabe na dose de $5 \mathrm{mg} / \mathrm{Kg} / \mathrm{sem}$ e $10 \mathrm{mg} / \mathrm{Kg} / \mathrm{sem}$, respectivamente. A expressão da proteína E-caderina na superfície apical das glândulas cólicas é semelhante nos três grupos.

Na Figura 5A, 5B e 5C observa-se a expressão tecidual da proteína E-caderina, na mucosa cólica sem trânsito fecal dos animais tratados por cinco semanas consecutivas com SF $0,9 \%$, infliximabe na dose de $5 \mathrm{mg} / \mathrm{Kg} / \mathrm{sem}$ e $10 \mathrm{mg} / \mathrm{Kg} / \mathrm{sem}$, respectivamente. Verifica-se que existe menor expressão da proteína E-caderina na superfície apical das glândulas cólicas, nos animas que receberam SF 0,9\%. Diferentemente, nos animais submetidos à intervenção com infliximabe, independente da dose utilizada, a presença da proteína E-caderina era nitidamente maior.

Na Figura 6, observa-se, nos segmentos com e sem trânsito intestinal, os valores encontrados para o conteúdo tecidual da proteína E-caderina, nos animais tratados com SF0,9\% e infliximabe nas dosagens de $5 \mathrm{mg} / \mathrm{kg} / \mathrm{sem}$ e $10 / \mathrm{mg} / \mathrm{kg} / \mathrm{sem}$ por cinco semanas. Os resultados mostram redução do conteúdo tecidual da proteína no cólon sem trânsito fecal nos animais que receberam intervenção com SF 0,9\% e infliximabe na dose de $5 \mathrm{mg} / \mathrm{Kg} / \mathrm{sem}$ quando comparados com os segmentos com trânsito fecal preservado. Nos animais tratados com infliximabe na dose de $10 \mathrm{mg} / \mathrm{kg} / \mathrm{sem}$ esses valores eram semelhantes aos do cólon com trânsito preservado. Verifica-se ainda, que nos

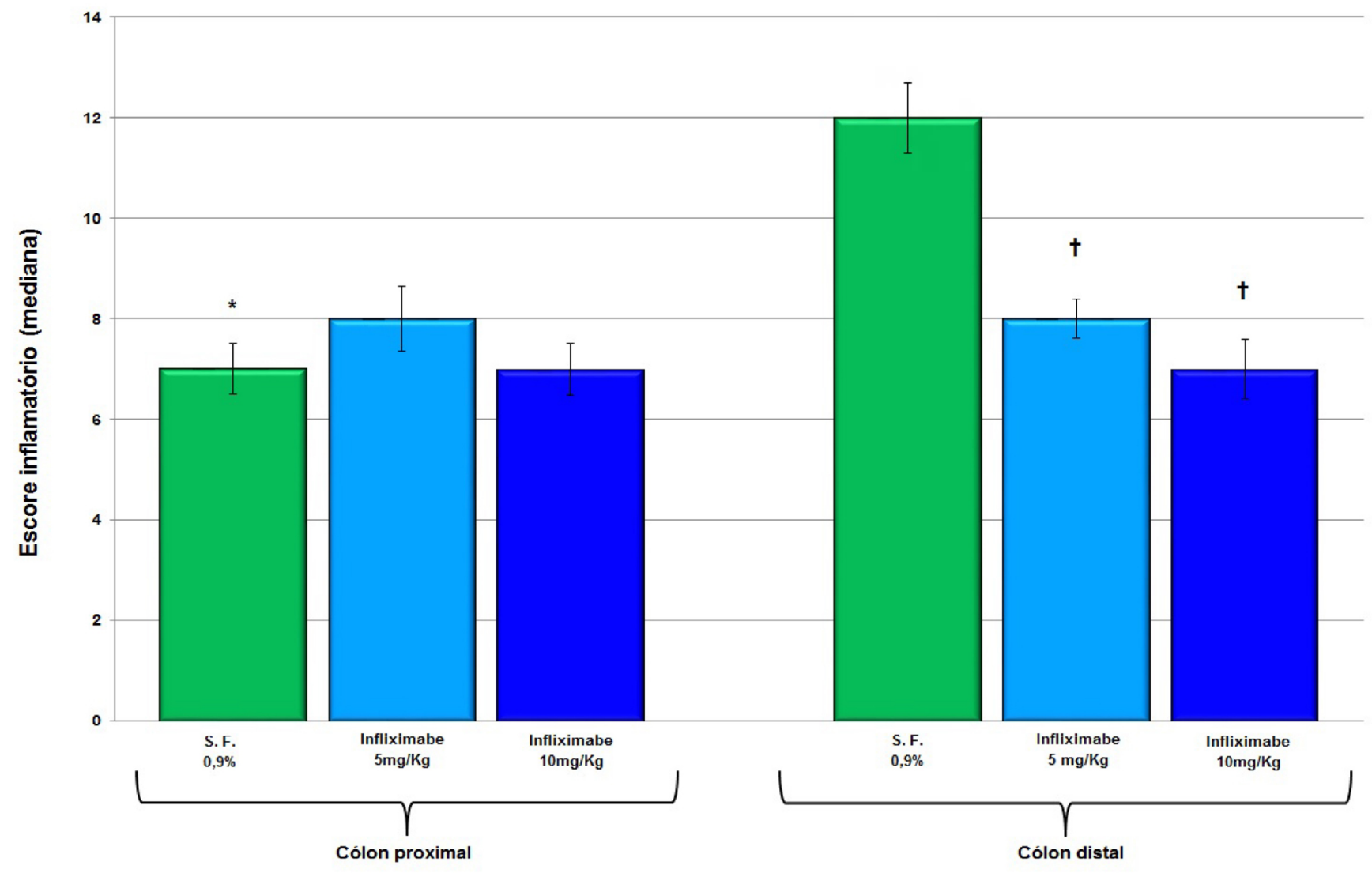

Figura 3 - Escore inflamatório nos cólons com e sem trânsito intestinal dos animais tratados com SF 0,9\%, infliximabe 5mg/ $\mathrm{Kg} / / \mathrm{sem}$ e infliximabe $10 \mathrm{mg} / \mathrm{Kg} / \mathrm{sem} .{ }^{*}=\mathrm{p}<0,05$ (SF 0,9\% sem trânsito $>$ SF 0,9* com trânsito). ${ }^{\dagger}=\mathrm{p}<0,05$ (Infliximabe $5 \mathrm{mg} / \mathrm{Kg} / \mathrm{sem}$ e Infliximabe $10 \mathrm{mg} / \mathrm{kg} / \mathrm{sem}$ sem trânsito < SF 0,9\% sem trânsito intestinal). Teste de Mann-Whitney.

A

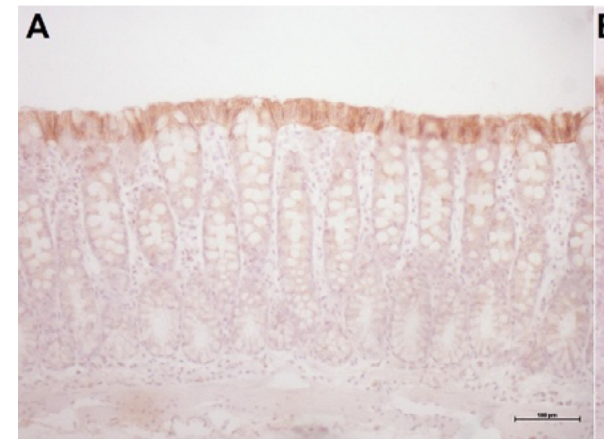

B

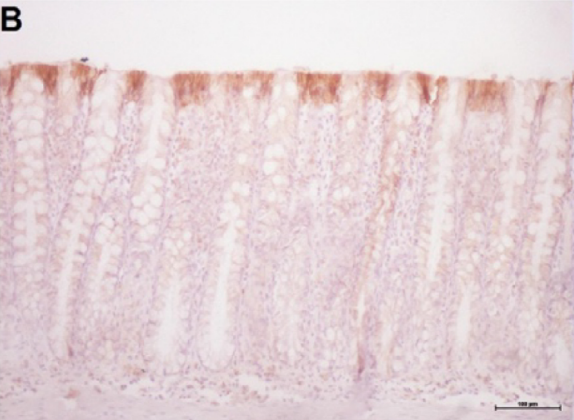

C

Figura 4 - A: Expressão tecidual da proteína E-caderina na mucosa cólica com trânsito intestinal dos animais com SF 0,9\%. B: Expressão tecidual da proteína E-caderina na mucosa cólica com trânsito intestinal dos animais com infliximabe na dose de $5 \mathrm{mg} / \mathrm{Kg} / \mathrm{sem}$. C: Expressão tecidual da proteína E-caderina na mucosa cólica com trânsito intestinal dos animais com infliximabe na dose de $10 \mathrm{mg} / \mathrm{Kg} / \mathrm{sem}$ (IH-E-caderina: 200x) 

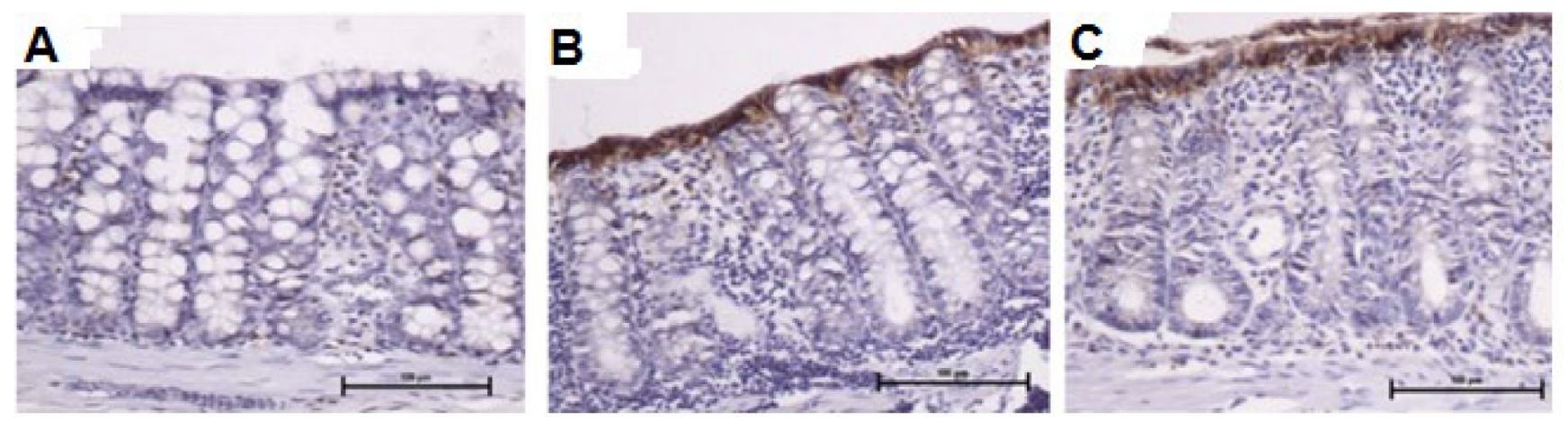

Figura 5 - A: Expressão tecidual da proteína E-caderina na mucosa cólica sem trânsito intestinal dos animais com SF 0,9\%. B: Expressão tecidual da proteína E-caderina na mucosa cólica sem trânsito intestinal dos animais com infliximabe na dose de $5 \mathrm{mg} / \mathrm{Kg} / \mathrm{sem}$. C: Expressão tecidual da proteína E-caderina na mucosa cólica sem trânsito intestinal dos animais com infliximabe na dose de $10 \mathrm{mg} / \mathrm{Kg} / \mathrm{sem}$ (IH-E-caderina: 200x)

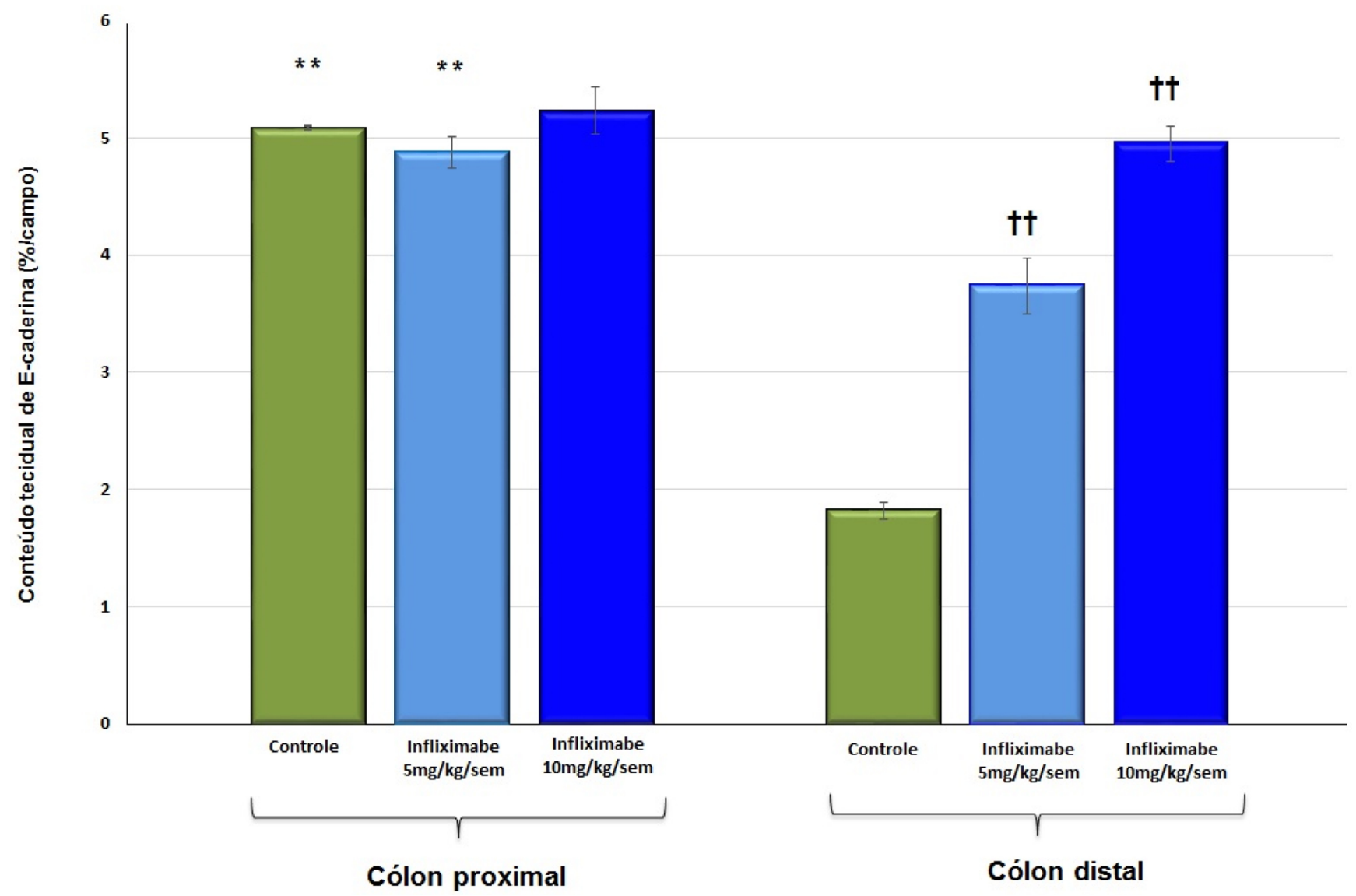

Figura 6 - Conteúdo tecidual de E-caderina nos cólons com e sem trânsito intestinal comparando animais com SF 0,9\%, infliximabe $5 \mathrm{mg} / \mathrm{Kg} / / \mathrm{sem}$ e infliximabe $10 \mathrm{mg} / \mathrm{Kg} / \mathrm{sem}$. * ${ }^{*}=\mathrm{p}<0,01$ (SF 0,9\% sem trânsito e infliximabe $5 \mathrm{mg} / \mathrm{kg} / \mathrm{sem}<\mathrm{SF} 0,9$ e infliximabe $5 \mathrm{mg} / \mathrm{Kg} / \mathrm{sem}$ no cólon com trânsito). ${ }^{\dagger+}=\mathrm{p}<0,01$ (Infliximabe $5 \mathrm{mg} / \mathrm{Kg} / \mathrm{sem}$ e Infliximabe $10 \mathrm{mg} / \mathrm{kg} / \mathrm{sem}$ sem trânsito intestinal > SF 0,9\% sem trânsito intestinal). Teste de Mann-Whitney.

segmentos sem trânsito fecal houve aumento do conteúdo de E-caderina nos animais tratados com infliximabe quando comparado aos tratados com SF 0,9\%. O aumento do conteúdo era mais evidente nos animais tratados com maior dose do infliximabe $(10 \mathrm{mg} / \mathrm{Kg} / \mathrm{sem})$.

Nas Figuras 7A, 7B e 7C observa-se a expressão tecidual da proteína claudina-3, na mucosa cólica com trânsito fecal dos animais submetidos a intervenção por cinco semanas consecutivas com SF 0,9\%, infliximabe na dose de $5 \mathrm{mg} / \mathrm{Kg} / \mathrm{sem}$ e $10 \mathrm{mg} / \mathrm{Kg} / \mathrm{sem}$, respectivamente. A expressão tecidual de claudina-3 é semelhante nos três grupos.

Nas Figuras 8A, 8B e 8C observa-se a expressão tecidual da proteína claudina-3, na mucosa cólica sem trânsito fecal dos animais tratados por cinco semanas consecutivas com
SF 0,9\%, inflixmab na dose de $5 \mathrm{mg} / \mathrm{Kg} / \mathrm{sem}$ e $10 \mathrm{mg} / \mathrm{Kg} / \mathrm{sem}$, respectivamente. Verifica-se que existe menor expressão da proteína claudina-3 na superfície apical das glândulas cólicas, nos animas que receberam SF $0,9 \%$. Diferentemente, nos animais submetidos à intervenção com infliximabe, independente da dose utilizada, a presença da proteína claudina-3 era nitidamente maior.

Na Figura 9, observa-se, nos segmentos com e sem trânsito intestinal, os valores encontrados para o conteúdo tecidual da proteína claudina-3, nos animais tratados com SF0,9\% e infliximabe nas dosagens de $5 \mathrm{mg} / \mathrm{kg} / \mathrm{sem} \mathrm{e} 10 / \mathrm{mg} / \mathrm{kg} / \mathrm{sem}$ por cinco semanas. Os resultados mostram redução do conteúdo tecidual da proteína no cólon sem trânsito fecal nos animais que receberam intervenção com SF 0,9\% e infliximabe na dose 


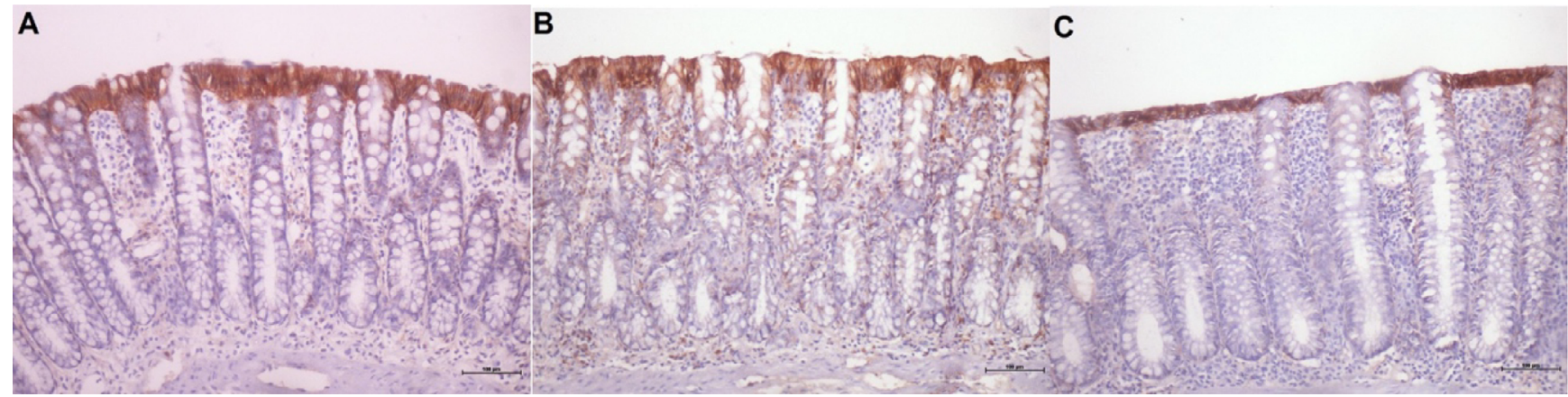

Figura 7- A: Expressão tecidual da proteína claudina-3 na mucosa cólica com trânsito intestinal dos animais com SF 0,9\%. B: Expressão tecidual da proteína claudina-3 na mucosa cólica com trânsito intestinal dos animais tratados com infliximabe na dose de $5 \mathrm{mg} / \mathrm{Kg} / \mathrm{sem}$. C: Expressão tecidual da proteína claudina-3 na mucosa cólica com trânsito intestinal dos animais com infliximabe na dose de $10 \mathrm{mg} / \mathrm{Kg} / \mathrm{sem}$ (IH-claudina-3: 100x).
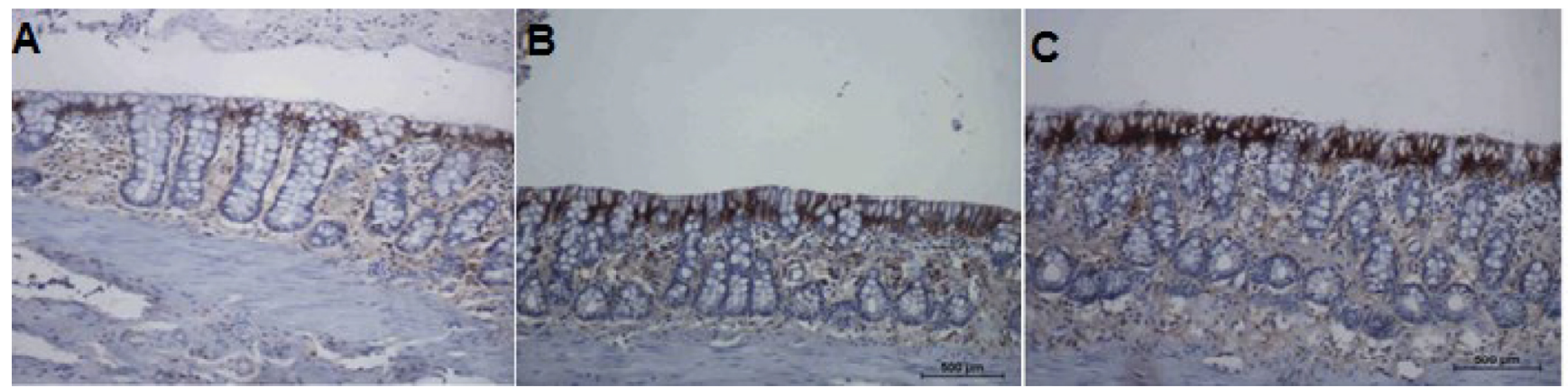

Figura 8 - A: Expressão tecidual da proteína claudina-3 na mucosa cólica sem trânsito intestinal dos animais com SF 0,9\%. B: Expressão tecidual da proteína claudina-3 na mucosa cólica sem trânsito intestinal dos animais com infliximabe na dose de $5 \mathrm{mg} / \mathrm{Kg} / \mathrm{sem}$. C: Expressão tecidual da proteína claudina-3 na mucosa cólica sem trânsito intestinal dos animais com infliximabe na dose de $10 \mathrm{mg} / \mathrm{Kg} / \mathrm{sem}$ (IH-claudina-3: 100x).

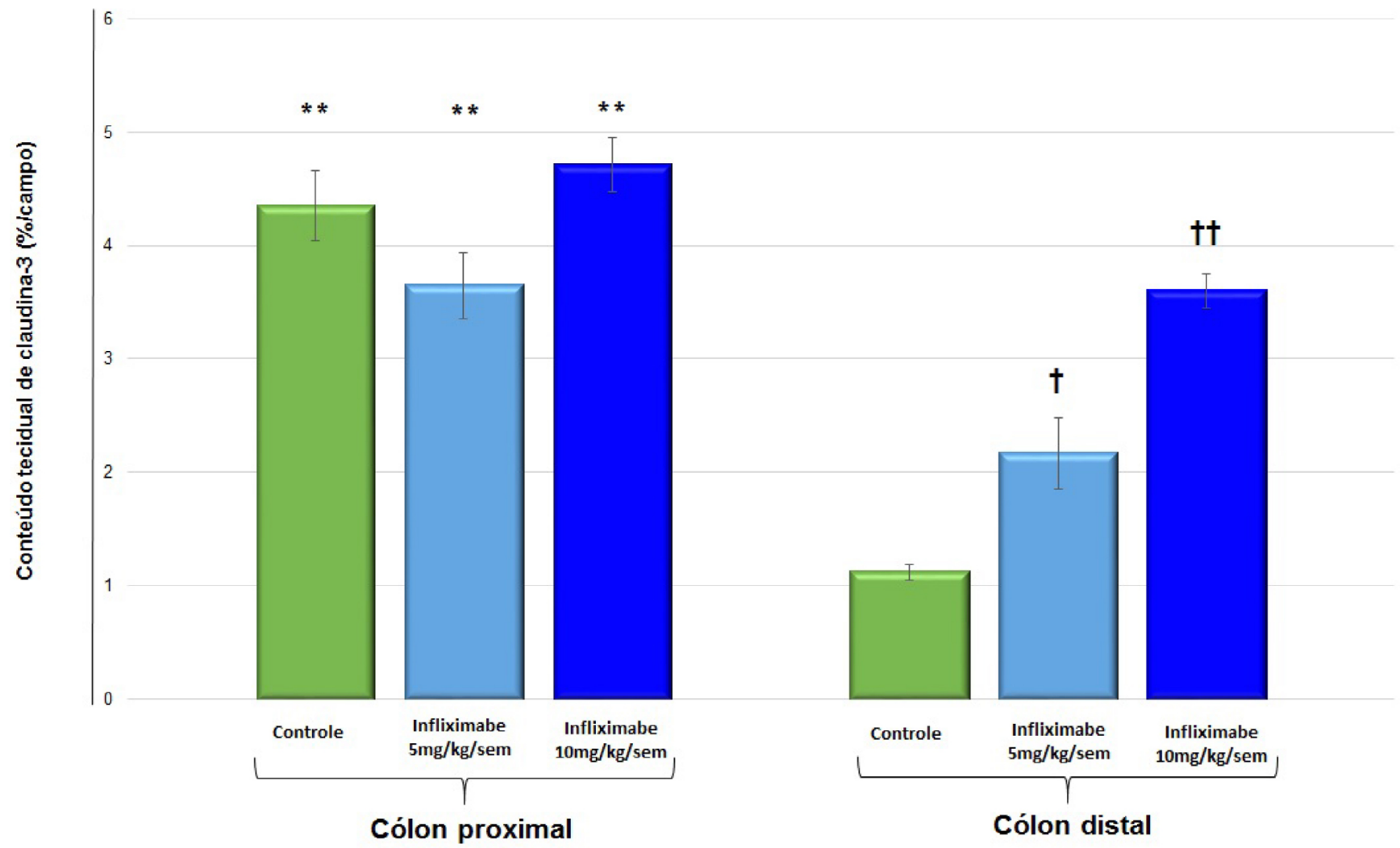

Figura 9 - Conteúdo tecidual de claudina-3 nos cólons com e sem trânsito intestinal comparando animais tratados com SF 0,9\%, infliximabe $5 \mathrm{mg} / \mathrm{Kg} / \mathrm{sem}$ e infliximabe $10 \mathrm{mg} / \mathrm{Kg} / \mathrm{sem}$. ${ }^{* *}=\mathrm{p}<0,01$ (SF 0,9\%, infliximabe $5 \mathrm{mg} / \mathrm{kg} / \mathrm{sem}$ e infliximabe $10 \mathrm{mg} / \mathrm{Kg} / \mathrm{sem}$ cólon com trânsito intestinal > SF 0,9\%, infliximabe $5 \mathrm{mg} / \mathrm{Kg} / \mathrm{sem}$ e infliximabe $10 \mathrm{mg} / \mathrm{Kg} / \mathrm{sem} \mathrm{no}$ cólon sem trânsito). $\dagger=p<0,05$ (infliximabe $5 \mathrm{mg} / \mathrm{Kg} / \mathrm{sem}$ cólon sem trânsito fecal $>\mathrm{SF} 0,9 \%$ cólon sem trânsito fecal. $+\dagger=p<0,01$ (Infliximabe $10 \mathrm{mg} / \mathrm{Kg} / \mathrm{sem}$ sem trânsito intestinal $>$ SF 0,9\% e infliximabe $5 \mathrm{mg} / \mathrm{Kg} / \mathrm{sem}$ sem trânsito intestinal). Teste de Mann-Whitney. 
de $5 \mathrm{mg} / \mathrm{Kg} / \mathrm{sem}$ quando comparados com os segmentos com trânsito fecal preservado. Nos animais tratados com infliximabe na dose de $10 \mathrm{mg} / \mathrm{kg} / \mathrm{sem}$ esses valores eram semelhantes aos do cólon com trânsito preservado. Verifica-se ainda, que nos segmentos sem trânsito fecal houve aumento do conteúdo de claudina-3 nos animais tratados com infliximabe quando comparado aos tratados com SF 0,9\%. O aumento do conteúdo era mais evidente nos animais tratados com maior dose do infliximabe ( $10 \mathrm{mg} / \mathrm{Kg} / \mathrm{sem})$.

\section{DISCUSSÃO}

Estudos utilizando modelos experimentais de CD demonstraram que existe aumento da produção de RLO a partir das células do epitélio cólico carentes do suprimento regular de $A C C C C^{4,6,19,26,28,30}$. A falta do suprimento regular de AGCC aos segmentos cólicos sem trânsito fecal, modifica, consideravelmente, os mecanismos de $\beta$-oxidação para obtenção de energia a partir dessas substâncias. Assim, o metabolismo energético das células desprovidas de seu principal substrato passa a depender de aminoácidos, particularmente, da glutamina, fornecida pelo suprimento sanguíneo arterial $17,24,25$. Entretanto, a eficiência energética obtida a partir da metabolização da glutamina não é suficiente para prover as células da mucosa cólica de todo o contingente necessário para manutenção da síntese de diferentes proteínas importantes na homeostase do ciclo celular, bem como, na preservação da integridade epitelial ${ }^{2,17,19}$. Os RLO, em especial o hidroxil $(\mathrm{OH})$, são radicais tóxicos para as diferentes estruturas lipoproteicas das células que formam o epitélio intestinal. O estresse oxidativo resultante da maior produção de RLO, danifica diferentes estruturas celulares e, entre elas, as proteínas que constituem os sistemas de adesão intercelular 1,12,18,19,26,28. Já se demonstrou que o estresse oxidativo destrói várias proteínas que formam a barreira epitelial da mucosa, representadas pela camada de muco, membrana citoplasmática, junções intercelulares e membrana basa|8,12,17,23. A ruptura da integridade epitelial possibilita a migração de bactérias presentes no lúmen intestinal para o meio interno fazendo com que ocorra uma intensa migração de células inflamatórias para o epitélio danificado, com o intuito de combater a translocação de antígenos e bactérias ${ }^{5}$. Como consequência, instala-se um processo inflamatório crônico que caracteriza e perpetua as alterações histológicas inflamatórias características da $\mathrm{CD}^{25}$.

A inflamação do epitélio intestinal carente do suprimento de AGCC compromete todos os mecanismos componentes da barreira epitelial da mucosa cólica ${ }^{2,3,25}$. Estudos avaliando as alterações histológicas da mucosa cólica de segmentos sem trânsito fecal encontraram modificações em todas as camadas que formam a parede do cólon 13,26,28,29. Mostrouse que existe redução da altura das glândulas cólicas nos segmentos derivados, e que essa atrofia epitelial torna-se mais significativa após seis semanas de exclusão, atingindo seu ápice após 12 semanas $^{29}$. Demonstrou-se que existe redução do peso da mucosa cólica de $10 \%$ após uma semana, $21 \%$ após duas semanas e $37 \%$ após quatro semanas de exclusão de trânsito intestinal ${ }^{14}$. A atrofia da parede cólica sem trânsito fecal, não obstante ser mais significativa na camada mucosa, também compromete as demais camadas da parede cólica ${ }^{13,14,29}$. Existe uma redução de $41 \%$ do peso no epitélio após quatro semanas e, $48 \%$ após 12 semanas $^{14}$. A suplementação de AGCC ou substâncias com atividade anti-inflamatório ou antioxidante melhora essa atrofia epitelial 13,6,20,26,28. Esses mesmos achados, também foram observados no presente estudo quando se verificou importante redução da altura das glândulas cólicas nos segmentos desprovidos de trânsito fecal dos animais do grupo que recebeu intervenção com SF 0,9\%. De modo distinto, nos tratados com infliximabe, a melhora do processo inflamatório mucoso nos segmentos exclusos de trânsito relacionou-se à recuperação da atrofia epitelial.

Quando se considera a camada de muco que recobre o epitélio cólico e que representa a primeira barreira de defesa da mucosa, a falta do fornecimento de AGCC também está relacionada a importantes alterações ${ }^{2,7,23}$. A modificação da produção e secreção de muco é uma das características da $C D^{7,23}$. O número de células caliciformes reflete o status de secreção de muco e, indiretamente, a atividade destas células. Keli et al em 1987, não conseguiram demonstrar uma diferença estatisticamente significativa do número de células caliciformes quando compararam os segmentos com e sem trânsito intestinal, todavia, mostraram que o conteúdo e o subtipo de mucina produzida se modificavam ao comparar-se segmentos com e sem trânsito fecal ${ }^{13}$. Nos segmentos com trânsito preservado as mucinas sulfatadas se localizavam no terço superior da cripta, enquanto as ricas em ácido siálico nos dois terços inferiores. De modo distinto, nos segmentos derivados, o conteúdo tecidual das sialomucinas praticamente desaparecia, enquanto o de sulfomucina aumentava progressivamente com o progredir tempo de derivação. Resultados semelhantes foram encontrados por outros autores ${ }^{23}$. Esses achados sugerem que a modificação na produção e a redução do conteúdo de mucinas no cólon excluso de trânsito, possa estar relacionada a falta de suprimento energético para produção de mucinas, bem com a destruição epitelial relacionada ao processo inflamatório local decorrente do maior estresse oxidativo tecidual ${ }^{7,23}$. Essa possibilidade fica ainda mais evidentes pelos resultados de estudos experimentais mostrando que a redução do processo inflamatório e do estresse oxidativo epitelial restabelece a produção de mucinas nos segmentos exclusos de trânsito ${ }^{1,2,7-9,28}$

O epitélio intestinal é formado por uma única camada de células com propriedades absortivas, intimamente aderidas entre si e à membrana basal ${ }^{12,17,18,23}$. A união das células epiteliais ocorre graças a sistemas de junções célula-célula, os quais suportam grande parte do estresse mecânico sobre a parede intestinal ${ }^{5}$. Para a manutenção da adesão celular, filamentos proteicos de actina, que formam o citoesqueleto celular, atravessam o citoplasma de cada célula unindo-se a junções especializadas localizadas na membrana plasmática. Existem três grupos funcionais de junções intercelulares: Junções de aderência, de oclusão e comunicantes ${ }^{8}$. A principal proteína das junções aderentes é a E-caderina, enquanto a principal proteína da junção de oclusão é a Claudina- $3^{8}$. A presença e o conteúdo tecidual de ambas refletem, indiretamente, a integridade da barreira epitelial ${ }^{12}$. O processo inflamatório que se instala nos segmentos desprovidos do suprimento regular de AGCC, também compromete as proteínas constituintes das junções intercelulares ${ }^{12,17,18,25}$. A destruição das proteínas constituintes das junções intercelulares, também foi descrita em portadores de DII ${ }^{1,8}$. Do mesmo modo, estudos utilizando modelos experimentais de CD também mostraram que existe comprometimento das proteínas que compõe a junções intercelulares. Kadri et al, em 2013, demonstraram que ocorre uma redução substancial no conteúdo tecidual de E-caderina nos segmentos cólicos desprovidos de trânsito intestinal ${ }^{12}$. De modo semelhante, outros autores também encontraram redução do conteúdo e $\beta$-catenina nas junções aderentes do cólon sem trânsito fecal ${ }^{17}$. Em ambos os estudos a redução do conteúdo das duas principais proteínas que constituem o sistema de junção aderente intercelular mostrava-se relacionada ao progredir do tempo de exclusão e ao estresse oxidativo tecidual ${ }^{12,17}$.

Estudo experimental que utilizou modelo de CD semelhante ao empregado no presente estudo mostrou que nos segmentos desprovidos do suprimento de AGCC existe redução do 
conteúdo tecidual de Claudina-3 e ocludina, as principais proteínas constituintes das junções de oclusão intercelular ${ }^{18}$. Os autores verificaram, que havia uma redução de $48 \%$ e 54\%, respectivamente, após 12 semanas de derivação intestinal ${ }^{18}$. Contudo, ao aplicarem enemas contendo extrato oleoso de curcumina, produto natural com destacada ação antioxidante $e$ anti-inflamatória, o conteúdo de ambas as proteínas aumentava significativamente ${ }^{18}$. Esses achados sugerem que a redução do conteúdo tecidual das principais proteínas que formam as junções de aderência e de oclusão intercelular poderia estar relacionada tanto ao estresse oxidativo quanto ao agravamento do processo inflamatório tecidual ${ }^{4,16,18}$. Esses achados confirmam resultados de estudos experimentais que mostraram a eficácia do emprego de antioxidantes na redução do estresse oxidativo tecidual, e melhora do processo inflamatório que se desenvolve no cólon sem trânsito fecal ${ }^{3,4,16,24}$. Já se demonstrou que em portadores de DII existe um aumento da expressão de genes relacionados a maior produção de citocinas pró-inflamatórias e redução da expressão de genes relacionados a transcrição das proteínas constituintes das junções intercelulares ${ }^{20}$. Esse mesmo estudo mostrou que a administração de infliximabe foi capaz de restaurar essas alterações. Da mesma forma, demonstrou-se experimentalmente que a administração de infliximabe é capaz de proteger a barreira epitelial em modelo experimental de colite quimicamente induzida e aumentar a produção tecidual de E-caderina ${ }^{1,20}$. O infliximabe, inibindo o fator de necrose tumoral alfa reduz a produção de enzimas proteolíticas, particularmente as metaloproteínas, responsáveis pela degradação das proteínas claudina e ocludina ${ }^{20}$

Apesar do conteúdo das proteínas E-caderina e claudina-3 ter sido estudado em diferentes situações clínicas e experimentais, do melhor do nosso conhecimento, seu conteúdo tecidual ainda não foi mensurado em modelos experimentais de $C D$ cujos animais foram submetidos ao tratamento com infliximabe. Um único estudo em modelo experimental de CD mostrou que o infliximabe reduz o processo inflamatório tecidual no cólon excluso, diminui a infiltração neutrofílica e melhora a cicatrização epitelial ${ }^{3}$. Esses resultados sugerem que a terapia biológica com infliximabe talvez seja uma proposta terapêutica interessante para o tratamento das formas graves de $C D^{3}$. Os níveis teciduais de fator de necrose tumoral alfa (TNF- $\alpha$ ) encontram-se aumentados na mucosa sem trânsito intestinal ${ }^{24}$. O infliximabe age neutralizando a atividade biológica do TNF- $\alpha$ ao impedir a ligação deste aos receptores específicos das membranas celulares, bloqueando a indução de citocinas pró-inflamatórias como as interleucinas 1 e $6^{26}$. O infliximabe diminui a migração de leucócitos por redução da permeabilidade da camada endotelial e expressão de moléculas de adesão, além de reduzir a atividade funcional de neutrófilos e eosinófilos ${ }^{26}$. Não obstante o infliximabe representar uma das mais importantes opções terapêuticas para o tratamento das DII, seu uso nas formas graves da CD humana ainda não foi avaliado. Assim torna-se relevante a realização de estudos experimentais que utilizem o infliximabe para tratamento da $C D$, avaliando seu papel na preservação da integridade dos mecanismos de defesa da barreira epitelial, como os formados pelas junções intercelulares.

O presente estudo além de confirmar a melhora do processo inflamatório da mucosa exclusa, como mostrado por Buainain et al., em 2019, mostrou que o uso do infliximabe aumentou o conteúdo tecidual de E-caderina e Claudina-3 à valores próximos aos encontrados no cólon com trânsito preservado. Esse aumento do conteúdo tecidual de ambas as proteínas foi mais evidente quando se utilizou doses maiores de infliximabe $(10 \mathrm{mg} / \mathrm{Kg} / \mathrm{sem})$, sugerindo uma relação dose-dependente. Esses achados sugerem que a diminuição do processo inflamatório tecidual decorrente do uso do infliximabe possibilite a recuperação dasjunções intercelulares e, indiretamente da barreira epitelial mucosa. É provável que a redução da infiltração neutrofílica determinada pelo infliximabe, também diminua a formação de RLO pelos neutrófilos reduzindo, consequentemente, o dano oxidativo local ${ }^{3,12,16-18,24}$.

Finalmente, a semelhança do que ocorre em outras DII, os resultados deste estudo sugerem que a ação terapêutica do infliximabe possa serconsiderada interessante proposta terapêutica para a CD. Contudo, a maior limitação do presente estudo é que esta avaliação foi realizada em modelo experimental utilizando ratos. Assim, a extrapolação dos resultados encontrados para seres humanos com formas graves de CD ainda merecem uma palavra de cautela. A comprovação da eficácia do infliximabe para o tratamento da $C D$ humana ainda necessita de comprovação em ensaios clínicos randomizados.

\section{CONCLUSÃO}

Infliximabe reduz o processo inflamatório da mucosa cólica exclusa do trânsito intestinal e aumenta o conteúdo tecidual das proteínas E-caderina e Claudina-3, principalmente nos animais tratados com maiores doses da substância. A terapia com infliximabe mostrou-se eficaz para o tratamento de $C D$ experimental.

\section{REFERÊNCIAS}

1. Agarwal VP, SchimmelEM. Diversion colitis: a nutritional deficiency syndrome? Nutr Rev. 1989;47(9):257-61. doi: 10.1111/j.17534887.1989.tb02857.x.

2. Alves AJ Júnior, Pereira JA, Pansani AH, Magro DO, CoyCS, Martinez CA. Tissue sulfomucin and sialomucin content in colon mucosa without intestinal transit subjected to intervention with Curcuma longa (curcumin). Acta Cir Bras. 2017;32(3):182-193. doi: 10.1590/ S0102-865020170030000002.

3. Buanaim RP, Pereira JA, Campos FG, Kotze PG, GotoEFK, Mendonça RLS, Kanno DT, Martinez CAR. Effects of anti-TNF- $\alpha$ in experimental diversion colitis. Acta Cir Bras. 2019;34(10):e201901004. doi: 10.1590/s0102-865020190100000004

4. Caltabiano C, Máximo FR, Spadari AP, da Conceição Miranda DD, Serra MM, Ribeiro ML, Martinez CA. 5-aminosalicylic acid (5-ASA) can reduce levels of oxidative DNA damage in cells of colonic mucosa with and without fecal stream. Dig Dis Sci. 2011;56(4):103746. doi: 10.1007/s10620-010-1378-z

5. Castilho TJC, Almeida GHDR, Mello EVSL, Campos ACL. Effect of supplementation with probiotics on colonic anastomoses in rats: morphological and tensiometric study. Arq Bras Cir Dig. 2021;33(4):e1550. doi: 10.1590/0102-672020200004e1550.

6. Cook SI, Sellin JH. Review article: short chain fatty acids in health and disease. Aliment Pharmacol Ther. 1998;12(6):499-507. doi: 10.1046/j.1365-2036.1998.00337.x.

7. Fernandez OOA, Pereira JA, Campos FG, Araya CM, Marinho GE, Novo RS, Oliveira TS, Franceschi YT, Martinez CAR. Evaluation of enemas containing sucralfate in tissue content of MUC-2 protein in experimental model of diversion colitis. Arq Bras Cir Dig. 2017;30(2):132-138. doi: 10.1590/0102-6720201700020012.

8. Finnie IA, Dwarakanath AD, Taylor BA, Rhodes JM. Colonic mucin synthesis is increased by sodium butyrate. Gut. 1995;36(1):93-9. doi: 10.1136/gut.36.1.93.

9. Gaudier E, Rival M, Buisine MP, Robineau I, Hoebler C. Butyrate enemas upregulate Muc genes expression but decrease adherent mucus thickness in mice colon. Physiol Res. 2009;58(1):111-119. doi: 10.33549/physiolres.931271.

10. Glotzer DJ, Glick ME, Goldman H. Proctitis and colitis following diversion of the fecal stream. Gastroenterology. 1981;80(3):43841. PMID: 7450438 . 
11. Harig JM, Soergel KH, Komorowski RA, Wood CM. Treatment of diversion colitis with short-chain-fatty acids irrigation. $\mathrm{N}$ Engl J Med. 1989;320(1):23-8. doi: 10.1056/NEJM198901053200105.

12. Kadri CJ, Pereira JA, da Silva CM, Nonose R, Nascimento EF, Jacomo $\mathrm{AL}$, Martinez CA. E-cadherin expression in colonic mucosa with and without fecal stream. J Invest Surg. 2013;26(2):72-9. doi: 10.3109/08941939.2012.693334.

13. Keli E, Bouchoucha M, Devroede G, Carnot F, Ohrant T, Cugnene $\mathrm{PH}$. Diversion related experimental colitis in rats. Dis Colon Rectum. 1997;40(2):222-8. Doi:10.1007/bfo2054992.

14. Kissmeyer-Nielsen $P$, Christensen $H$, Laurberg S. Diverting colostomy induces mucosal and muscular atrophy in rat distal colon. Gut. 1994;35(9):1275-81. doi: 10.1136/gut.35.9.1275.

15. Korelitz BI, Chesckin LJ, Sohn N, Sommers SC. The fate of the rectal segment after diversion of the fecal stream in Crohn's disease: its implications for surgical management. J Clin Gastroenterol. 1985;7(1):37-43. doi: 10.1097/00004836-198502000-00005.

16. Martinez CA, de Almeida $M G$, da Silva $C M$, Ribeiro $M L$, da Cunha FL, Rodrigues MR, Sato DT, Pereira JA. Enemas with $\mathrm{N}$-acetylcysteine can reduce the level of oxidative damage in cells of the colonic mucosa diverted from the faecal stream. Dig Dis Sci. 2013;58(12):3452-9. doi: 10.1007/s10620-013-2768-9.

17. Martinez CAR, Fabris FM, Silva CMG, Rodrigues MR, Sato DT, Ribeiro ML, Pereira JA. Oxidative stress and changes in the content and pattern of tissue expression of $B$-catenin protein in diversion colitis. J. Coloproctol. 2012; 32(4): 343-358. doi.org/10.1590/ S2237-93632012000400001.

18. Martinez CA, Kadri CJ, Kanno DT, Alves AJ Júnior, Coy CS, Pereira JA. Claudin-3 and occludin content in the glands of colonic mucosa devoid from fecal stream submitted to topical intervention with oil extract of Curcuma longa. Acta Cir Bras. 2017;32(1):65-73. doi: 10.1590/s0102-865020170108.

19. Martinez CA, Ribeiro ML, GamberoA, Miranda DD, Pereira JA, Nadal SR. The importance of oxygen free radicals in the etiopathogenesis of diversion colitis in rats. Acta Cir Bras. 2010;25(5):387-95. doi: 10.1590/s0102-86502010000500002.

20. Mehta S, Nijhuis A, Kumagai T, Lindsay J, Silver A. Defects in the adherensjunction complex(E-cadherin/B-catenin) in inflammatory bowel disease. Cell Tissue Res. 2015;360(3):749-60. doi: 10.1007/ s00441-014-1994-6.
21. Morson BC, Dawson IMP. Gastrointestinal Pathology, first ed., Blackwellfic Publications, London, 1972. PMCID:PMC1769935.

22. NassriCGG, Nassri AB, FaveroE, Rotta CM, MartinezCAR, Margarido NF.Influence of irrigation of nutritional solutionsinthe colon excluded of fecal stream. Experimental study in rats. Rev Bras Coloproct. 2008;28(3):306-31. doi: 10.1590/S0101-98802008000300006.

23. Nonose R, Spadari AP, Priolli DG, Máximo FR, Pereira JA, Martinez $C A$. Tissue quantification of neutral and acid mucins in the mucosa of the colon with and without fecal stream in rats. Acta Cir Bras. 2009;24(4):267-75. doi: 10.1590/s0102-86502009000400005.

24. Oliveira AJ, Pinto Júnior FE, Formiga MC, Melo SP, Brandao-Neto J, Ramos AM. Comparison of prophylactic and therapeutic use of short-chain fatty acid enemas in diversion colitis: a study in Wistar rats. Clinics (Sao Paulo). 2010;65(12):1351-6. doi: 10.1590/s180759322010001200020. Erratumin:Clinics(Sao Paulo).2011;66(2):365.

25. Pravda J. Radical induction theory of ulcerative colitis. World J Gastroenterology. 2005;11(16):2371-84. doi: 10.3748/wjg.v11. i16.2371.

26. Rutgeerts $P$, Sandborn WJ, Feagan BG, Reinisch W, Olson A, Johanns J, Travers S, Rachmilewitz D, Hanauer SB, Lichtenstein $G R$, et al. Infliximab for induction and maintenance therapy for ulcerative colitis. N Engl J Med. 2005;353(23):2462-76. doi: 10.1056/NEJMoa050516. Erratum in: N Engl J Med. 2006 May 18;354(20):2200.

27. Santos BRMD, Santos CHMD, Santos VRMD, Torrez CYG, PalomaresJunior D. predictive factors for loss of response to anti-TNFin Crohn's disease. Arq Bras Cir Dig. 2020;33(2):e1522. doi: 10.1590/0102$672020200002 \mathrm{e} 1522$.

28. Scheppach W, Christl SU, Bartram HP, Richter F, Kasper H. Effects of short-chain fatty acids on the inflamed colonic mucosa. Scand J GastroenterolSuppl.1997;222:53-7.doi:10.1080/00365521.1997.11720719.

29. Sousa MV, Priolli DG, Portes AV, Cardinalli IA, Pereira JA, Martinez CA. Evaluation by computerized morphometry of histopathological alterations of the colon wall in segments with and without intestinal transit in rats. Acta Cir Bras. 2008;23(5):417-24. doi: 10.1590/ s0102-86502008000500005.

30. Tedelind S, Westberg F, Kjerrulf M, Vidal A. Anti-inflammatory properties of the short-chain fatty acids acetate and propionate: a study with relevance to inflammatory bowel disease. World J Gastroenterol.2007;13(20):2826-32.doi:10.3748/wjg.v13.i20.2826. 